Revista Iberoamericana, Vol. LXXVII, Núm. 234, Enero-Marzo 2011, 111-133

\title{
EL SILENCIOSO VIAJE DE LA IDEOLOGÍA: EL “PACO YUNQUE” DE VALLEJO Y LA ADAPTACIÓN DE JUAN ACEVEDO
}

\author{
POR \\ Gustavo Faverón Patriau \\ Bowdoin College
}

La tarde de 1931 en que César Vallejo envió a su editor el manuscrito del cuento "Paco Yunque”, colocó entre sus páginas un rápido garabato, de trazo infantil, con la anotación "aquí van los dibujos que debe hacer el dibujante de la editorial” (Fig. 1). Más de medio siglo después, el historietista Juan Acevedo recogió la invitación como propia y fue más allá, transponiendo el relato completo al lenguaje del cómic, recolocándolo en la historia de la crítica social en el Perú con las modificaciones que, desde su perspectiva, el tiempo había depositado en el texto original. ${ }^{1}$

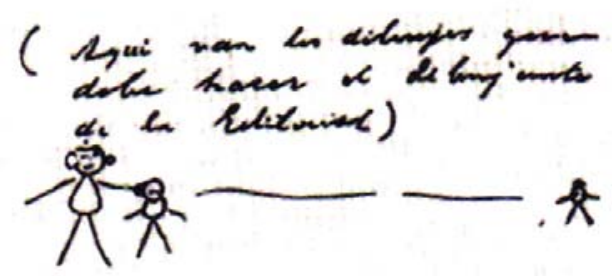

Fig.1 Dibujo de César Vallejo y anotación para sus editores (1931).

El cuento de Vallejo transcurre, como la versión de Acevedo, íntegramente en un solo escenario, el interior cerrado de una escuela primaria en alguna provincia del Perú. El rasgo claustrofóbico, sin embargo, sirve para enfatizar el contraste entre interior y exterior, y para hacer del primero una cifra del segundo. "Paco Yunque y su madre llegaron a la puerta del colegio", se lee en la primera línea del relato de Vallejo: "la madre le dejó y se fue” (389). Desde allí hasta el final, ese único evento exterior -el traslado de

1 Juan Acevedo (Lima, 1949) es acaso el historietista crucial del cómic peruano contemporáneo. Autor de Paco Yunque y la novela histórica Túpac Amaru (1985). Es creador también de las dos tiras cómicas de comentario social más populares del país: El Cuy y Pobre diablo. Es autor, asimismo, de la voluminosa Historia de Latinoamérica desde los niños (1995). 
la casa a la escuela-subrayará la reclusión posterior del niño y la mecánica del colapso que sufre en el encierro. "You see the full significance of this myth of outside and inside in alienation, which is founded on these two terms", decía Jean Hyppolite, según recuerda Gaston Bachelard (212): la alienación, es decir, el emplazamiento impropio de un sujeto en un medio que lo rechaza, se materializa en la oposición de dentro y fuera. En la historieta de Acevedo, el exterior es presentado como un vacío absoluto, en el que fugazmente existen Paco y su madre, entrevistos, de espaldas, alejándose o adentrándose en un universo desconocido (Fig. 2):

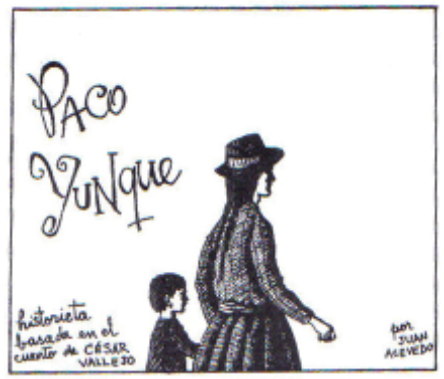

Fig. 2. Pag. 1 Viñeta 1.

En el cuento de Vallejo, la impresión primera de Paco en la escuela es la extrañeza: los demás niños parecen actuar “como si estuviesen en su casa” (389), una falsedad tan ostensible que resulta sospechosa e indescifrable para Paco. En su caso, sólo la presencia de la madre es señal de familiaridad; su ausencia, por tanto, enfatiza el desamparo y la ajenidad. "Pensó en su casa y en su mamá”, escribe Vallejo (391): ambos términos son inseparables. Pronto sabemos que Paco es un niño del campo, traído a la ciudad, a vivir en la casa donde su madre es sirvienta, para hacerle compañía al hijo de los patrones. Alienado en el nuevo escenario, sólo su madre es síntoma de pertenencia. "Yo vivo con mi mamá”, dice, ante cierta pregunta. “¿En la casa de Humberto Grieve?”, le replican. Y su respuesta esquiva la intención del interrogatorio: "Es una casa muy bonita. Ahí está la patrona y el patrón. Ahí está mi mamá. Yo estoy con mi mamá” (394). La razón de la elusión es compleja. La identificación de madre y hogar como una unidad -“original shell”, para usar la frase de Bachelard (4)- se ve obstaculizada por la condición de servidumbre en la que Paco y su madre ocupan la casa. Acevedo recoge el trazo de Vallejo y lo acentúa, formulando un paralelismo entre la situación de ambos ante la escuela (Fig. 3) y la condición de ambos en la casa (Fig. 4):

Revista Iberoamericana, Vol. LXXVII, Núm. 234, Enero-Marzo 2011, $111-133$
ISSN 0034-9631 (Impreso) 


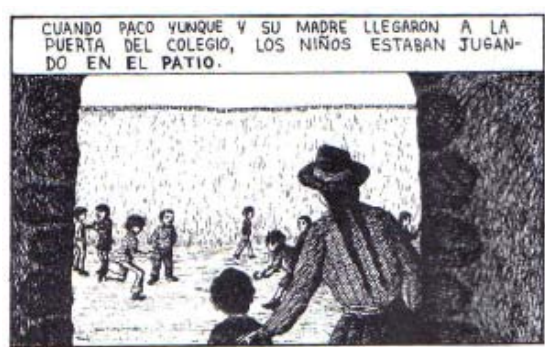

Fig. 3. Pag. 1. Viñeta 2.

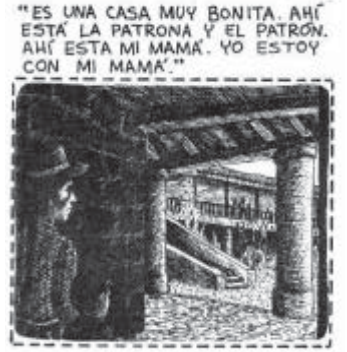

Fig 4. Pag. 6. Viñeta 3.

Colocados ante los dos recintos donde transcurrirá la vida del niño, madre e hijo resultan liminares, marginales, detenidos en el umbral; reunidos, sí, pero empujados a la periferia: deben formar parte de un mundo que apenas alcanzan a ver desde fuera, como extraños. La pregunta que pone Vallejo en labios de Paco es, por ello, doblemente dramática: “¿A qué hora se iría a su casa?”, piensa (401). Sabemos que también en casa es un extraño, no menos que en la escuela. En el texto original, la respuesta a una interrogante sobre la ubicación de su casa queda indeterminada -“¿está lejos?”, le dicen. “Sí... no", responde (391)-; en la versión de Acevedo, una viñeta abierta, liberada del rigor del marco, desliza una respuesta trascendente: la flor de retama (Fig. 5), motivo recurrente de los cantos andinos, permite entender que la verdadera casa de Paco no está en la ciudad:
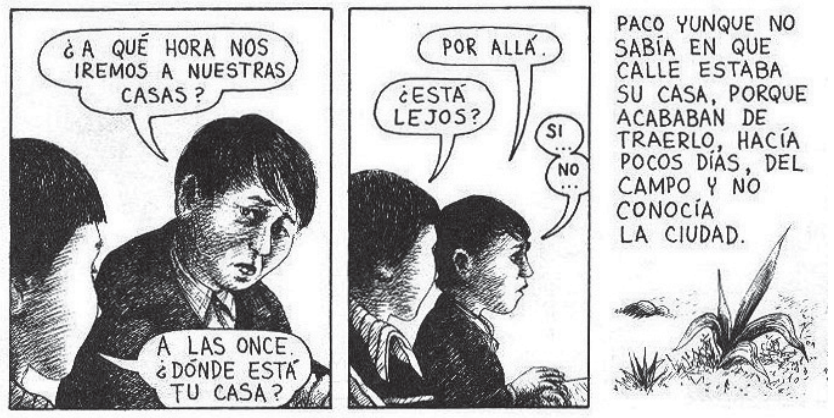

Fig. 5. Pag. 3. Viñetas 7, 8 y 9 .

“There are as many spaces as there are distinct spatial experiences”, escribe Michel de Certeau (118): la llegada de Paco a la nueva casa, primero, y su ingreso en el colegio, de inmediato, lo colocan en la posición de experimentar los nuevos espacios y darles un orden mediante ese ejercicio. Convertir a la madre en cifra del hogar, aun si ella y él son

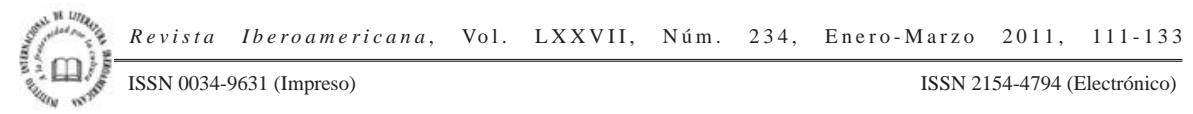


ajenos a la casa, es una operación defensiva y difícil, pero instantánea y simbólicamente primaria. Más compleja es la búsqueda siguiente: dar forma organizada al aparente caos que representa el colegio, un lugar sin estructura evidente, desconocido, caótico en apariencia, y ásperamente violento ante los ojos del niño. ${ }^{2}$ Su primera mirada de la escuela subraya ambos rasgos: violencia y caos, o, todavía más específicamente, la violencia como producto del caos. En el texto de Vallejo, la cadena causal se construye poco a poco: “Esto era un enredo”, dice Paco ante el laberinto de gritos, carreras y alaridos que pueblan el patio durante el recreo (389), y, más adelante, ante los primeros brotes belicosos, es el caos el que engendra la violencia: "llovieron bofetadas y patadas entre varios niños. Esto era un enredo” (404). En Acevedo, el dédalo de aullidos y golpes es reconocido como tal por Paco en el momento exacto en que su madre lo deja y se marcha (Fig. 6): con ella se va el principio organizador de la mirada del niño.

Fig. 6 Pag. 1. Viñeta 4.

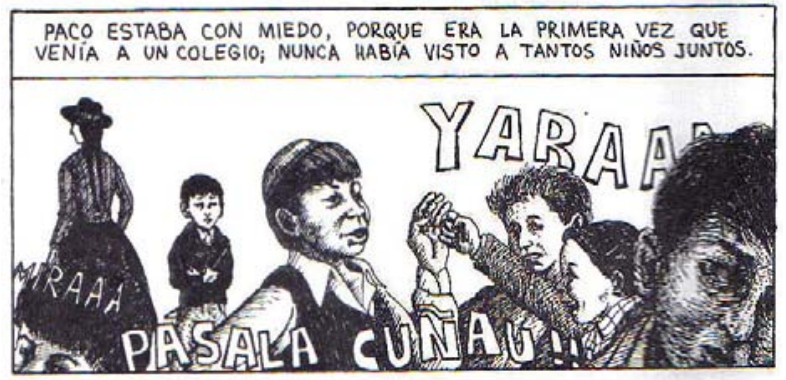

Carente de ese referente ordenador, la mirada de Paco se hace errabunda y es incapaz de otorgar sentido a los signos que lo rodean: "Miraba a hurtadillas al profesor, al pupitre, al muro que había detrás del profesor y al techo”, describe Vallejo (391). En cierto sentido, el cuento es la historia del descubrimiento de la lógica espacial de la escuela en medio de lo que originalmente parece ser un lugar irregulado y sin normas, sin forma apreciable. Vallejo, poeta al fin y al cabo, descubre una manera sutil de ir visibilizando la estructura en medio del aparente caos: la mera repetición de motivos organizadores, que señalan la regularidad de los movimientos de niños y maestros: "un traqueteo de carpetas y todos los alumnos ya estaban sentados” (390); "un traqueteo de carpetas y todos los alumnos estaban ya sentados” (404); "un traqueteo de carpetas y

\footnotetext{
"All really inhabited space bears the essence of the notion of home... The imagination functions in this direction whenever the human being has found the slightest shelter: we shall see the imagination build 'walls' of impalpable shadows, comfort itself with the illusion of protection-or, just the contrary, tremble behind thick walls, mistrust the staunchest ramparts” (Bachelard 5).
}

ISSN 0034-9631 (Impreso) 
todos los niños estaban ya sentados” (406). Acevedo mantiene el mecanismo, pero lo expande de manera interesante, permitiendo que la repetición se vuelva leitmotiv y que, además, abra la primera línea intertextual de su historieta, vinculándola con otra que, según propongo, le sirve de subtexto. Vallejo escribe: “en ese momento sonó la campana y todos entraron a los salones de clase”. Acevedo atiende a la repetición y decide cambiar la percusión de las carpetas por la de las campanas, permitiendo que, en el dibujo, la soga del repique marque la línea fronteriza entre esos dos nuevos espacios que pasan a formar la estructura del mundo infantil en la escuela: el patio y las aulas (Fig. 7). Fig. 7. Pag. 1. Viñeta 10

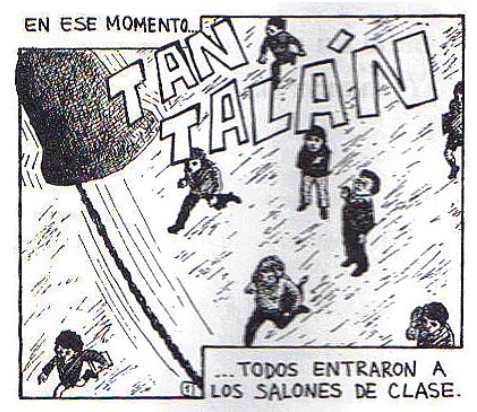

La partición señala también, a la vez, el ingreso de Paco en el innatural mundo de las obligaciones gregarias y los órdenes de solidaridad, poder y sojuzgación que se reproducen en la escuela, como veremos, a imagen y semejanza del mundo exterior. Esa frontera, entonces, señalada por la cuerda de la campana como demarcación territorial y por el retumbo de su son, separan al Paco solitario y ensimismado del Paco capturado y obligado a seguir las normas, atrapado por manos desconocidas, forzado a la obediencia (Fig. 8).

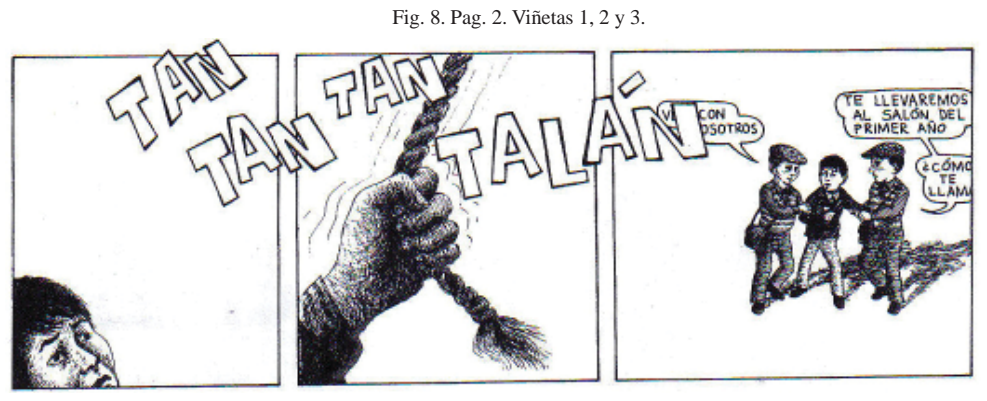

Revista Iberoamericana, Vol. LXXVII, Núm. 234, Enero-Marzo 2011, $111-133$
ISSN 2154-4794 (Electrónico) 
El ingreso de la referencia intertextual a la que aludí antes es modesto, sutil, pero no por ello menos visible. El leitmotiv de las campanas, repetido en Paco Yunque, era ya piedra de toque en la estructura gráfica de una obra previa de Acevedo, su Túpac Amaru, novela de corte histórico, que queda hasta la fecha trunca en el segundo de cuatro volúmenes proyectados. Es un vínculo irónico el que establece Acevedo. En el imaginario popular peruano, en el espectro de los íconos andinos, pocas imágenes son tan antitéticas como las del indefenso y apocado Yunque vallejiano y el bravío y orgulloso rebelde que estuvo a punto de traer abajo la tramoya del aparato colonial en el sur andino a fines del siglo dieciocho. La aparición de la campana de Túpac Amaru (Fig. 9) en Paco Yunque, entonces, no es sólo un rasgo ordenador en el andamiaje espacial de esta última, la clave de la frontera transpuesta y el inicio del encierro, sino la primera advertencia de que ambas historias han sido dibujadas en contrapunto: que en ambas se hablará de opresión y revuelta, de poder y autoridad y de lucha hegemónica y dominación.

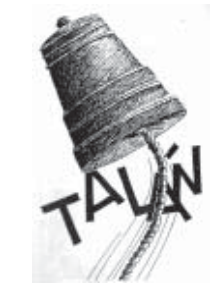

Fig. 9. De Túpac Amaru. Vol. 2. Pag. 45

La extrañeza de Paco a su ingreso en el colegio es la de alguien que percibe en un cierto escenario un exceso vital de elementos que lo apabullan, y es inhábil para notar la forma en que se interrelacionan. Al Paco de Vallejo lo afectan por igual el ruido -“esto del colegio era una bulla fuerte” (389)- como su ausencia -"este silencio le dio miedo a Paco" (390). Acevedo multiplica los efectos de esa aprensión del niño ante lo desconocido, mediante el recurso de fundir gráficamente ruido y silencio, convirtiéndolos a ambos en una sola entidad, en la que el sonido excesivo y su ausencia se interpenetran y se asfixian, cada vez en espacios más pequeños pero con mayor estridencia (Fig. 10).
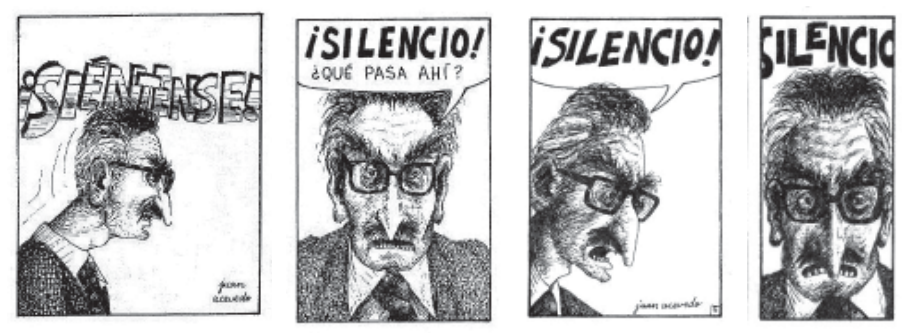

Fig. 10: Pag. 2. Viñeta 11. / Pag. 4. Viñeta 7./ Pag. 5. Viñeta 11. / Pag. 6. Viñeta 9.

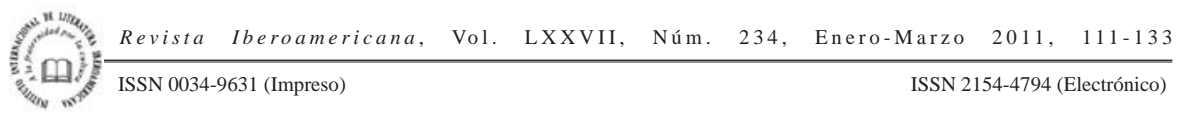


Si nos propusiéramos establecer el problema en términos tomados de Michel de Certeau, esta sería la más simple formulación: Paco se encuentra exiliado y añorando un lugar propio, estable, conocido, inmóvil, invariable, que él identifica vicariamente con su madre. ${ }^{3}$ A la vez, se encuentra sumergido en un espacio dinámico, cambiante, punto de intersección de imparables vectores de movimiento, que él no comprende y que, en vista de ello, percibe como caos (“bulla”, “enredo”). ${ }^{4} \mathrm{Al}$ mismo de Certeau pertenece la idea de que "every story is a travel story-a spatial practice", y que la construcción de una narración produce a la vez "geographies of actions” y conduce hacia "the commonplaces of an order" (116). En un sentido crucial, tanto el relato de Vallejo como la historieta de Acevedo lidian explícitamente con esa noción: el protagonista es un renuente cartógrafo, un navegante asustado de su mar. Su "práctica espacial”, su esperanza de sobrevivencia, está en comprender la mecánica de los órdenes construidos y enfrentados en el espacio que ahora le toca ocupar. La escuela es un espacio, es decir, un lugar con unas ciertas prácticas: en tanto son desconocidas, todas ellas son para Paco signos ambiguos, cuando no ilegibles. Ignora su emplazamiento en esa trama -“era la primera vez que venía a un colegio” (389)-, y lo busca arrimándose al centro y a los bordes del escenario, alternativamente: "paso a paso, fue adelantándose al centro del patio” (389); "se pegó a la pared” (389); “parado en medio del salón” (390); "Paco se pegó más a la pared” (389); "al entrar al salón se puso pálido” (390); “ahí, solo, parado, en el colegio” (390). La fluctuación es inconsciente, pero intuitiva: Paco rehúye el protagonismo pero se siente observado, intenta disfrazarse y desaparecer pero es innumerables veces empujado al lugar más visible. Pronto, en el relato de Vallejo, quedará clara su posición: es un marginal, pero es también el centro de la expectativa del abusivo Humberto Grieve, su compañero de curso, hijo de sus patrones.

En la versión de Acevedo, como corresponde, el descubrimiento es, para el lector, visual. En lugar de recurrir a un ordenamiento gráfico que incida en las nociones de centro y periferia, es decir, las dos que gobiernan el texto de Vallejo, Acevedo prefiere abundar en la otra dualidad, ya insinuada desde el principio (Figs. 3 y 4): la dicotomía de dentro y fuera, que es, después de todo, la versión radical y última del par anterior. Tres veces en el relato recurrirá a variaciones de una misma imagen: un personaje de pie bajo el umbral de la puerta de acceso al aula de clase, ingresando del vacío exterior al interior detallista del salón, y en las tres figuras la sola variación estará no en el contenido eminentemente gráfico, que se mantiene sin trastrueque, sino en el estatus del personaje representado (Fig. 11).

3 "A place (lieu) is the order (of whatever kind) in accord with which elements are distributed in relationships of coexistence. It thus excludes the possibility of two things being in the same location (place)... A place is thus an instantaneous configuration of positions. It implies an indication of stability” (de Certeau 117).

4 "A space exists when one takes into consideration vectors of direction, velocities, and time variables. Thus space is composed of intersections of mobile elements” (de Certeau 117).

$\begin{array}{llrrr}\text { Revista Iberoamericana, Vol. LXXVII, Núm. 234, } & \text { Enero-Marzo 2011, } 111-133 \\ \text { ISSN 0034-9631 (Impreso) }\end{array}$ 

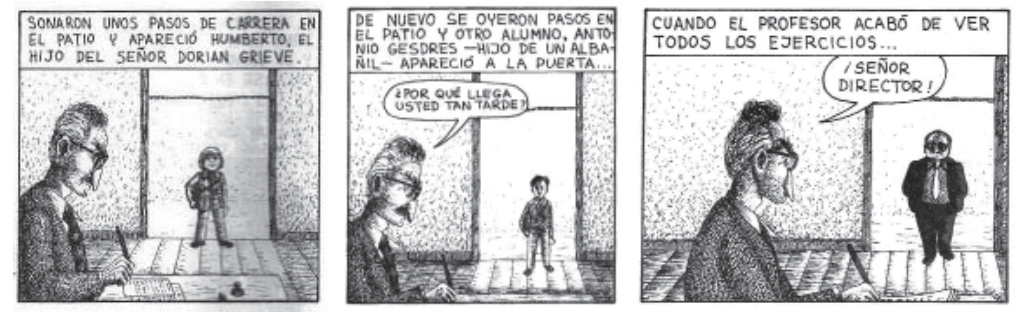

Fig. 11. Pag. 3. Viñeta 10 / Pag. 5. Viñeta 6. / Pag. 18. Viñeta 1.

El primero es el niño Humberto Grieve, hijo del hombre más rico del pueblo, su alcalde, y patrón de los Yunque; el segundo es Antonio Gesdres, hijo de un albañil; el tercero es el director de la escuela, que ingresa al salón sin incidentes ni resistencia. Los dos primeros han llegado tarde a clase, pero, mientras que a Grieve se le permite entrar sin más trámite que una reprimenda culposa, al segundo se le detiene, se le reconviene y finalmente se le reserva un castigo. En el texto de Vallejo se hace explícita la pena: "párese ahí", le dice el maestro, y le señala "un rincón, cerca de la pizarra” (393). En la historieta de Acevedo, la explicitud de ensancha: el dedo con que el profesor señala hacia "allí” traspone el marco de la viñeta (Fig. 12) , el rincón reservado para Gesdres se mantiene siempre fuera de la mirada del lector, y el espacio del castigo, así, se elide, se borra, se vuelve ausencia: la dinámica del dentro y el fuera anuncia su alcance: la silueta de Antonio Gesdres no vuelve a asomar en el relato visual: expulsado de la historieta, queda expulsado de la historia.

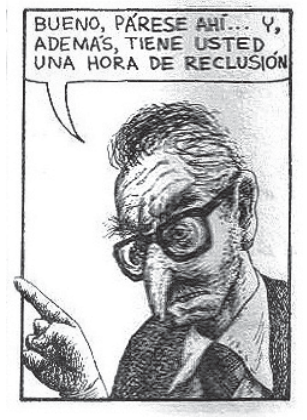

Fig. 12. Pag. 5. Viñeta 9.

Aun antes de ello, el relato de Acevedo se ha encargado de ir llenando de sentido el espacio originalmente vacío del aula, dotándolo de una historia y de referentes significativos. El maestro pasa a ocupar el lugar elevado del pupitre, los alumnos se empequeñecen en la magnitud del salón, y sobre ellos pesa una cadena de imágenes

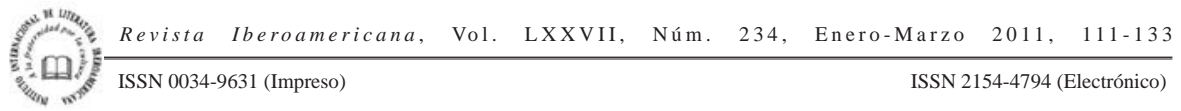


que Acevedo incorpora y que no son aludidas en el cuento de Vallejo: los retratos de Hipólito Unanue, precursor de la independencia peruana, y del almirante Miguel Grau y el coronel Francisco Bolognesi, los dos héroes mayores del periodo republicano. El primer encuentro de Paco con la escuela marca también su ingreso en el Perú oficial, y el contraste entre esos muros cubiertos de íconos nacionales y la puerta desierta del colegio (Fig. 13), en la que ha desaparecido ya la silueta de la madre (ver Fig. 3), subraya el proceso de construcción, ante los ojos del niño, del colegio como espacio dinámico, escenario de fuerzas, relatos y discursos, ya no como lugar inmóvil e inalterable, y cada vez menos como arcano y significante a ser llenado.

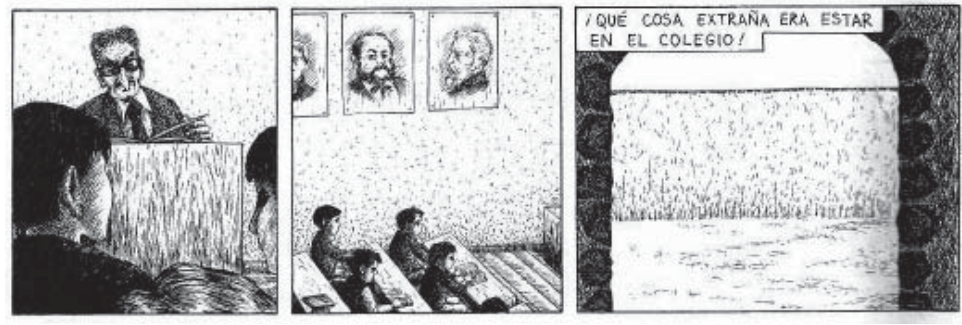

Fig. 13. Pag. 3. Viñetas 3, 4 y 5.

Así, de ser un lugar desprovisto de sentidos inteligibles para Paco-“a determination through objects that are ultimately reducible to the being-there of something dead" (de Certeau 118)-, la escuela se transforma en un espacio -“a determination through operations which [...] specify "spaces” by the actions of historical subjects" (118)-. Pero, ¿cuáles son exactamente esas operaciones? ¿Cuál el objeto que tales operaciones quieren modificar? ¿Cuál el statu quo del lugar que esas operaciones convierten en un espacio? Tanto el cuento de Vallejo como la adaptación de Acevedo dedican un tramo largo a una discusión particular, una conversación que los niños sostienen a instancias del profesor, y cuyo tema es la suerte que corren los peces al ser extraídos del agua. En Vallejo, el primero en responder a la pregunta del profesor es uno de los gemelos Zumiga: "Señor -dijo Zumiga- había en la playa mucha arena. Un día nos metimos entre la arena y encontramos un pez medio vivo y lo llevamos a mi casa. Pero se murió en el camino” (395). La evocación del niño es rápidamente reemplazada por otra, la de Humberto Grieve: "Yo he cogido muchos peces y los he llevado a mi casa y los he soltado en mi salón y no se mueren nunca” (395), dice. Sus compañeros le replican: “Mentira, señor. Porque el pez se muere pronto, cuando lo sacan del agua” (395). Entonces Grieve propone una seudoexplicación, astillada en frases caprichosamente unidas por el causal “porque”: “Porque en mi salón no se mueren. Porque mi salón es muy elegante. Porque mi papá me dijo que trajera peces y que podía dejarlos sueltos entre las sillas" (395). La respuesta de los demás es inmediata: "Era una gran mentira

Revista Iberoamericana, Vol. LXXVII, Núm. 234, Enero-Marzo 2011, $111-133$
ISSN 0034-9631 (Impreso) 
lo que contaba Grieve” (395). Grieve, sin embargo, continúa dotando de formalismos seudológicos a su explicación: "Porque mi papá tiene mucha plata. Y me ha dicho que me va a hacer llevar a mi casa a todos los peces del mar. Para mí. Para que juegue con ellos en mi salón grande" (396). En ese punto, queda revelado el verdadero sustento de las afirmaciones de Grieve: sus palabras no son ciertas por su valor de verdad, o por su grado de referencialidad, sino porque se basan en la posición del niño en la escala social. De hecho, la voz narrativa, internándose furtivamente en la memoria del personaje, descubre que el mismo Grieve no está seguro de sus aseveraciones: "Grieve recordaba que trajo dos peces pequeños a su casa y los soltó en su salón y ahí estuvieron muchos días [...] No estaba seguro si vivieron muchos días o murieron pronto. Grieve, de todos modos, quería que le creyeran lo que decía" (396). Y luego regresa sobre las alegaciones que conectan, como antes, verdad y dinero: "Mi papá puede darles aire en mi casa, porque tiene bastante plata para comprar todo" (396). La respuesta es una burla general coreada por toda la clase: “ ¡Miente, señor! ¡Ja! ¡Ja! ¡Ja! ¡Ja! ¡Ja! ¡Mentira! ¡Mentira!” (395). En ese momento la narración de Vallejo propone un paralelo: el profesor, alternativamente, reformula la pregunta, dirigida primero a Grieve y luego a Paco Yunque: "Si se le saca del agua, ¿qué sucede con el pez?”, dice primero. “Va a vivir en mi salón —contestó Grieve” (397). “¿Qué pasa con el pez, si se le saca del agua?”, inquiere después. “Los peces mueren fuera del agua porque les falta aire” (397), contesta Paco. Los demás lo apoyan, y el profesor anota la versión mayoritaria en la pizarra. La verdad, o lo que parece ser la verdad, queda restaurada, pero también ha quedado claro que, sólo desde la posición de Grieve, hijo del hombre más poderoso del pueblo, incluso la verdad más obvia es pasible de duda y queda comprometida. "The extreme form of power is All against One, the extreme form of violence is One against All”, escribía Hannah Arendt (42): en el cuento de Vallejo, solamente en ese breve episodio, el poder es ejercido por la mayoría, desde abajo, contra el más fuerte, que aún, sin embargo, es capaz de ejercer violencia contra todos los demás. La adaptación de Acevedo añade un vector nuevo al pasaje: la historia del niño que saca al pez de la arena para verlo morir más tarde es mostrada en un recuadro evocativo, enmarcado por líneas intermitentes (Fig. 14); el realismo del dibujo corresponde a la índole veraz de la historia contada. Después, sin embargo, el mismo trazo es puesto a recomponer visualmente el relato de Grieve, y el resultado es onírico, surrealista. El paralelismo, sin embargo, efectúa una operación de mayor interés: propone que la verdad en boca del niño pobre tiene un estatuto similar al de la mentira en los labios del niño rico (Fig. 14).

\footnotetext{
ISSN 0034-9631 (Impreso)
} 


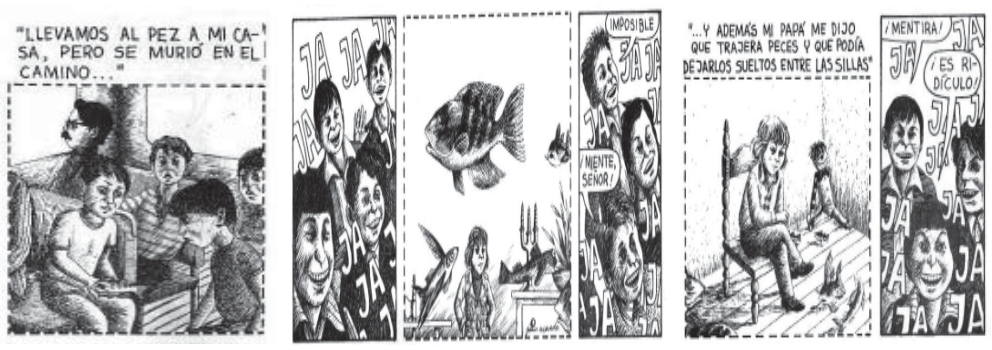

Fig. 14. Pag 7. Viñeta 3. / Pag. 7. Viñeta 9. / Pag. 7. Viñeta 13.

Es decir, incluso si la mayoría de los niños supone que Grieve está mintiendo, Acevedo postula esa pequeña forma de indecisión, casi subrepticia, que otorga a la falsedad del poderoso un estatuto de contrapeso a la verdad del débil: "The truth of a promise or a prognosis depends not only on the truthfulness but also on the authority of the person who utters it”, afirmó Pierre Bourdieu en su célebre estudio seminal sobre el lenguaje y el poder simbólico (190). En el pasaje referido, Acevedo coloca al centro de su relato el tema crucial del mismo, en su personal interpretación de Vallejo: si el "Paco Yunque" del poeta trujillano era una exploración más o menos demostrativa sobre la repetición de las estructuras sociales al interior de la escuela, la versión de Acevedo será una querella acerca del valor de verdad de los discursos producidos desde esa estructura, y un estudio del escenario del colegio no en tanto espejo o microcosmos del mundo social, sino en tanto uno de sus fundamentos, es decir, el colegio visto como lo que Althusser llamaba un Aparato Ideológico del Estado. De allí que, en ciertos pasajes, Acevedo desvíe la atención del diálogo entre los niños para centrarlo en un personaje que, en Vallejo, era menos central: el profesor, eje de la escuela en su rol ideológico. La Fig. 15 muestra una de esas instancias: ante la discrepancia entre la mayoría de los niños y Grieve, y las acusaciones de falsedad de unos contra el otro, es el profesor quien otorga veracidad a las palabras del niño rico: el dibujo de Acevedo reduce al profesor a una fracción de su cabeza: es la máquina pensante tomando la decisión de adosar veracidad a la mentira, si esa operación permite el mantenimiento de la jerarquía: la explosión de gritos irritados de los niños, al principio de la secuencia, muta en silencio una vez que el profesor ejerce su propio poder para dilucidar el choque entre los discursos enfrentados:

\footnotetext{
Revista Iberoamericana, Vol. LXXVII, Núm. 234, Enero-Marzo 2011, 111-133 


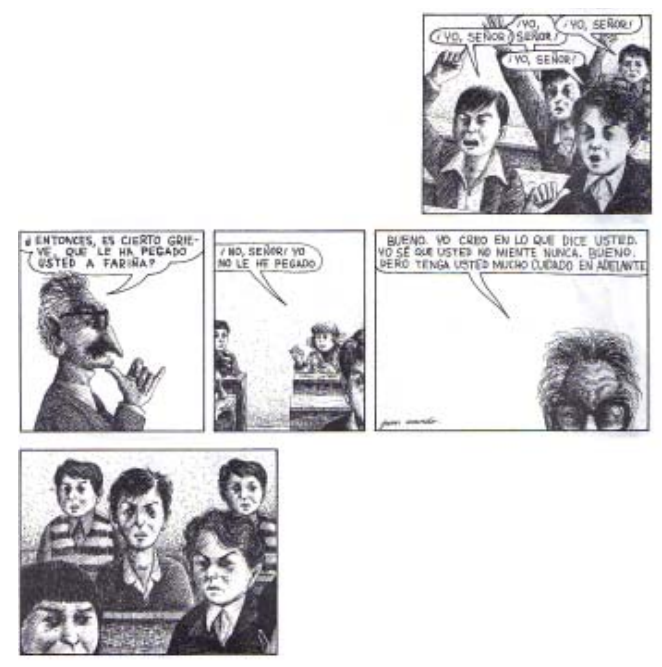

Fig. 15. Pag. 1. Viñetas 7, 8, 9, 10 y 11.

Habitualmente, concebimos la escuela, en tanto Aparato Ideológico del Estado, como un mecanismo homogéneo y homogeneizante, que refleja las articulaciones de un discurso hegemónico y lo transmite, como una forma de sujeción que forma individuos dentro del marco discursivo de las élites conductoras de la sociedad. Althusser, sin embargo, nunca otorgó a los Aparatos Ideológicos del Estado esa naturaleza de apariencia inmutable y exenta de contradicciones que con frecuencia vemos en ellos. "The Ideological State Apparatuses may be not only the stake, but also the site of class struggle”, prevenía, sobre esto, el marxista-estructuralista (113): dichos Aparatos Ideológicos del Estado no son ramificaciones brotadas más allá de la dinámica de la lucha por el campo hegemónico: son su primer escenario, están sujetos a la dialéctica de los discursos rivales y a la belicosidad de los sujetos detrás de esos discursos. El Paco Yunque de Acevedo se aproxima al cuento de Vallejo pero mantiene esa discrepancia de por medio: si el protagonista poeta, ese Paco inicial que ha sido consagrado en el canon peruano, es poco menos que "reducible to the being-there of something dead", como decía De Certeau, es decir, un cuerpo semi-inerte en un lugar construido de vacíos o tendiente al vacío, el Paco de Acevedo es detonante de una lucha por la hegemonía que toma como campo de batalla a la escuela y como facetas rivales, por un lado, al maestro y la familia Grieve y, por otro, a los demás chicos de la clase. ${ }^{5}$

5 Eso se debe a que Paco Yunque, en efecto, es el "pez fuera del agua” en ese mundo que le es por completo ajeno: de allí la centralidad que le otorgan Vallejo y Acevedo a la discusión literal de la frase, tratando de incidir, sugerentemente, en su valor metafórico.

ISSN 0034-9631 (Impreso) 
Decía Althusser: "The Ideological State Apparatuses function massively and predominantly by ideology, but they also function secondarily by repression, even if ultimately, but only ultimately, this is very attenuated and concealed, even symbolic" (112). Es en ese entresijo donde Acevedo construye su versión del relato de Vallejo: en el esbozo de un Aparato Ideológico del Estado que, parcialmente inutilizado en sus mecanismos de persuasión ideológica (los estudiantes no están dispuestos a aceptar la palabra de Grieve como verdad), se convierte en teatro de una lucha represiva, en la que uno solo quiere sobreponerse a todos los demás: "the extreme form of violence" de Arendt: "One against All” (42). ¿Cómo edifica Acevedo esa otra y nueva versión de la historia? ¿Cómo consigue heroizar la figura de Paco sin modificar los hechos del relato, es decir, sin cambiar en apariencia la historia del Paco pusilánime de Vallejo? Los recursos son varios. Por una parte, ahonda una pista dejada por Vallejo en el cuento original, donde se insinúa la dualidad del protagonista en la presencia de otro niño que lleva el mismo nombre, Paco Fariña ${ }^{6}$. Este "otro Paco" (391) comparte el origen humilde de Yunque, pero no su sumisión ni su disposición al sufrimiento: “¿A mí? ¡Qué me va a pegar a mí! Le pego un puñetazo en el hocico y le echo sangre” (400), dice Paco Fariña, cuando Paco Yunque le pregunta si de él también abusa el niño Humberto Grieve. La dualidad está sugerida en muchos otros rasgos: la duplicación de los gemelos Zumiga, que toman a Paco de los brazos y lo jalonean en direcciones opuestas (390), como harán también, más tarde, Paco Fariña y Humberto Grieve (392): "Fariña fue y tomó a Paco Yunque por la mano y quiso volver a traerlo a su carpeta, pero Grieve tomó a Paco Yunque por el otro brazo y no lo dejó moverse” (392). La imagen se repite, ciertamente, en el cuento de Vallejo, pero Acevedo la reformula y, al hacerlo, recobra el hilo que había dejado pendiente en el leitmotiv de la campana de Túpac Amaru. Por un lado, está este Paco que, como escribe Vallejo, "se dejaba jalar como un trapo por Fariña y por Grieve” (393). Por otro lado, Paco Fariña, que se enfrenta abiertamente a Grieve y se opone a los abusos físicos a los que, a partir de cierto momento, el niño rico insiste en someter a "su muchacho". Llegado un punto, durante el recreo, Grieve decide usar a Paco como un potro de salto, obligándolo a postrarse, doblado en dos por la cintura, cara abajo, para permitir que él lo salte por encima y le propine, en cada lanzamiento, una patada. Fariña le reclama a su homónimo: “¡Por qué te dejas saltar así y dar de patadas! ¡Pégale! ¡Sáltalo tú también! ¿Por qué te dejas?” (403). El dibujo de Acevedo regresa sutilmente a la mecánica de los paralelismos: del terreno abierto del patio desaparecen los referentes, quedan sólo las siluetas de los tres niños implicados y la pequeña nube de espectadores. Paco cae sobre el suelo, tendido, ante un golpe de Grieve: las piernas del agredido se abren hacia atrás, en direcciones opuestas; su libro

6 Aunque la obra narrativa de Vallejo no ha sido estudiada en ese aspecto, es cierto que el tema del doble no le es ajeno en lo más mínimo. De hecho, es la matriz anecdótica y simbólica de una de sus narraciones más logradas, el cuento fantástico "Fabla salvaje”, de 1923.

ISSN 0034-9631 (Impreso) 
vuela hacia el tercer ángulo del recuadro, su lápiz hacia la cuarta esquina: la disposición del dibujo repite la forma de aquella tortura con que los españoles del Cusco quisieron desmembrar al líder rebelde José Gabriel Condorcanqui, Túpac Amaru, a fines del siglo dieciocho, atando sus extremidades a cuatro caballos lanzados a correr en direcciones opuestas. Más importante aúun: el dibujo se aproxima a la disposición con que Acevedo representó esa escena en su Túpac Amaru (Fig. 16).

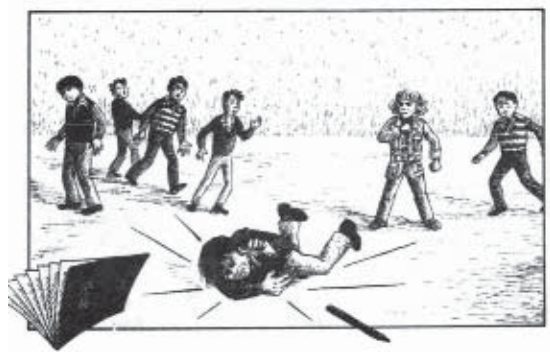

Fig. 16. Pag. 15.

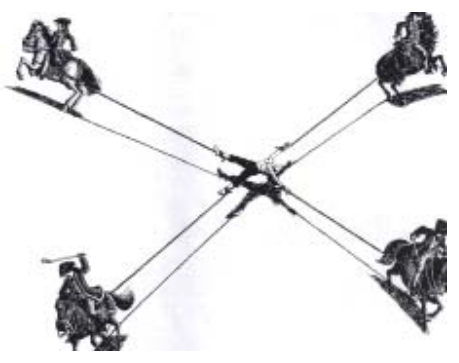

Viñeta 4. / De Túpac Amaru. Vol. 1. Pag. 1.

A partir de allí, todo lo gobierna un complejo juego de suplantaciones, paralelismos y metonimias. La larga y violenta secuencia que recoge los abusos de Paco a manos de Grieve está hecha de reiteraciones y aproximaciones: una carrera, un salto, una patada en la grupa, animal, los ojos pendientes de los observadores. El acercamiento y el encuadre viajan de la lejanía inicial, en la que Yunque es un objeto apenas visible, al acercamiento pleno, donde en su rostro luce el reflejo de un dolor físico arrasador, tan profundo que parece necesitar una explicación más allá de la circunstancia actual de la pequeña tortura infantil (Fig. 17).
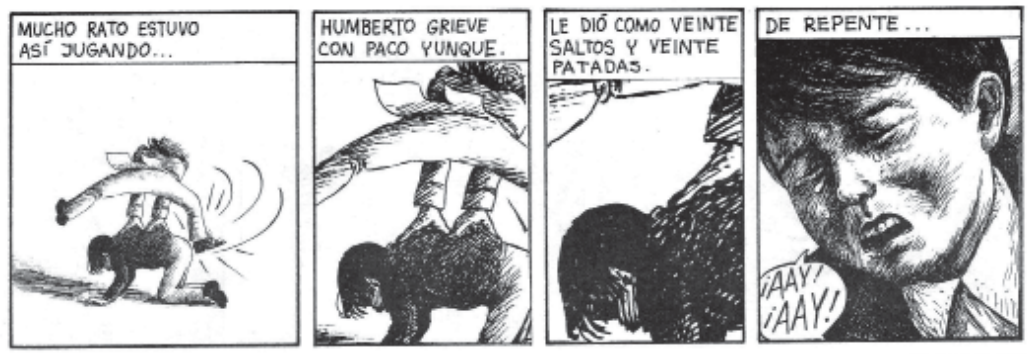

Fig. 17. Pag. 16. Viñetas 1, 2, 3 y 4 .

Y, en efecto, encontramos el origen de esa resonancia: el rostro de Paco en el cuarto cuadro de esa secuencia es el mismo que hemos visto páginas antes (Fig. 18), como

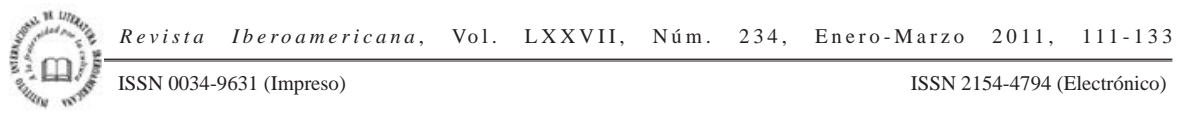


respuesta no al dolor físico, sino, crucialmente, ante la violencia de la actitud con que Grieve insistía en defender sus mentiras como verdades innegables, en el pasaje sobre los peces fuera del agua.
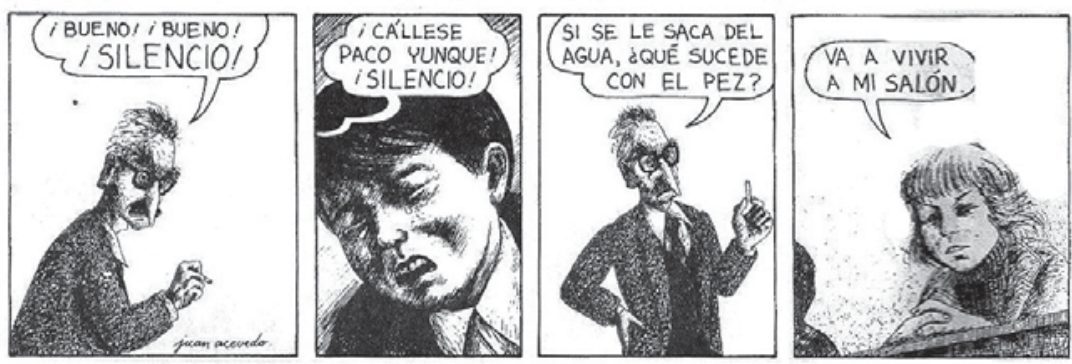

Fig. 18. Pag. 9. Viñetas 6, 7, 8 y 9.

Al proponer ese paralelo, Acevedo, efectivamente, duplica las líneas de lectura de allí en más: ningún dolor psíquico de Paco es sólo psíquico, ninguno físico es sólo físico: del control "por la ideología” a la pura represión, la escuela como Aparato Ideológico del Estado actúa sobre él recurriendo a las dos herramientas, como advertía Althusser, en simultáneo: queda desatada la contienda, en la versión de Acevedo el relato se convierte en una indagación sobre los mecanismos de la propagación ideológica hegemónica y las luchas para resistirla -de allí la centralidad que cobra el paralelo tupacamarista-. De inmediato, la vinculación de Paco Yunque y Túpac Amaru se multiplica: con el niño tumbado en el suelo, es su doble en rebeldía, el insumiso Paco Fariña, quien toma su lugar, y, apenas eso se produce, los cuadros de Paco Yunque parecen empeñarse en evocar, uno tras otro, los cuadros con que, en Túpac Amaru, Acevedo representaba al joven y aun escolar cacique enfrentándose a sus rivales ideológicos en el colegio de curacas del Cusco:

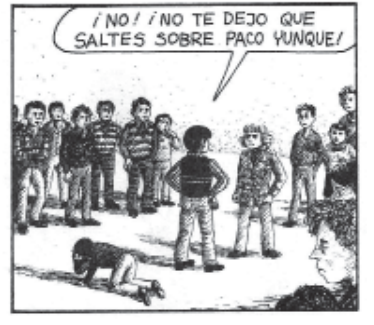

Fig. 19. Pag. 16.

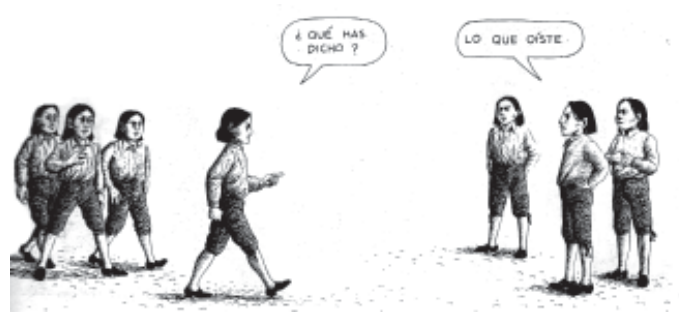

Viñeta 5. Derecha: De Túpac Amaru. Vol. 1. Pag. 29.

Revista Iberoamericana, Vol. LXXVII, Núm. 234, Enero-Marzo 2011, $111-133$
ISSN 2154-4794 (Electrónico) 


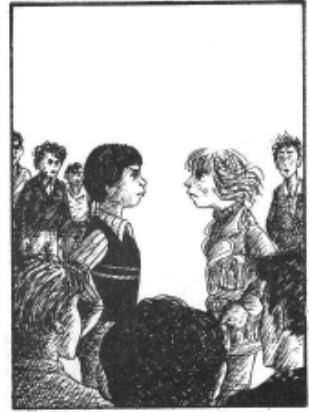

Fig. 20. Pag. 16.

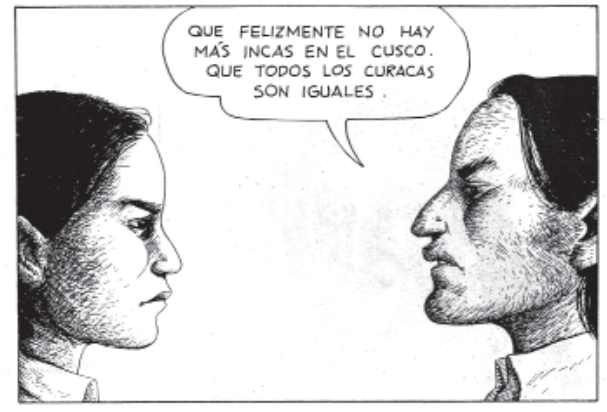

Viñeta 9. Derecha: De Túpac Amaru. Pag. 29.

Decía Bourdieu: "the legitimate point of view of the authorized spokesperson [...] as an official definition of one's official identity, saves its bearers from the symbolic struggle of all against all, by establishing the authorized perspective, the one recognized by all and thus universal, from which social agents are viewed" (240). Es esa legitimidad del punto de vista (del punto de vista de Grieve) la que cae bajo sospecha y se vuelve objetivo de la lucha en el interior del colegio. Y, siguiendo la misma línea de razonamiento, es la sospechada ilegitimidad de Grieve, su puesta en entredicho, la que da lugar al enfrentamiento de "all against all” (Fig. 21): una vez más, en Acevedo, el núcleo de la disputa en el relato es el contrabalance de poder y violencia como recursos finales para la canonización de la mirada hegemónica o su reemplazo por, en este caso, la mirada popular: es la veracidad de ambos discursos la que queda en la picota.
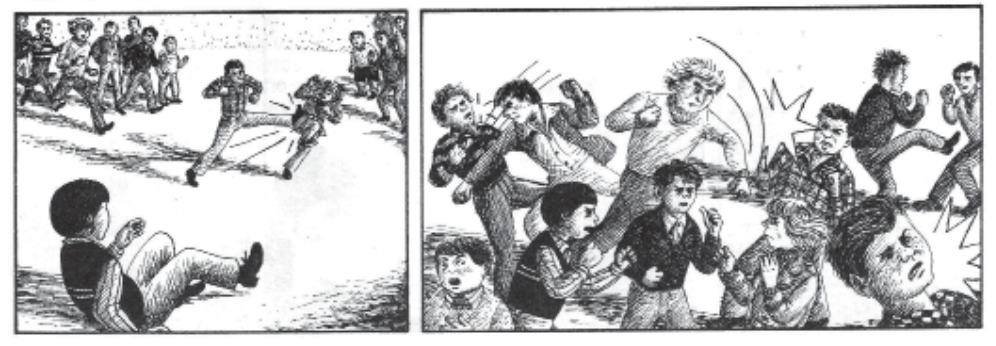

Fig. 21. Pag. 16. Viñetas 11 y 12.

Describiendo el rol de la escuela entre los Aparatos Ideológicos del Estado, Althusser señaló su carácter mimético, su tendencia a la aparente desaparición, al camuflaje: la escuela, decía Althusser, "has the dominant role, although hardly anyone lends an ear to its music: it is so silent!” (118). Elaborando sobre ello, el filósofo francés explicaba el genio de ese mecanismo de invisibilización: el primer componente ideológico transmitido

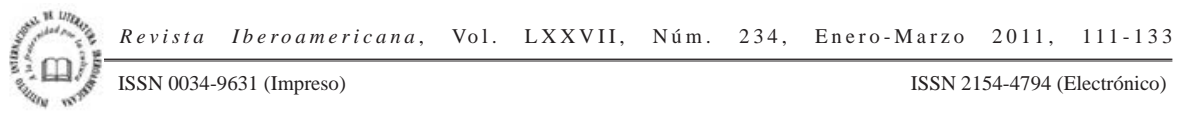


por la escuela es, precisamente, la idea de que ella misma es "a neutral environment purged of ideology” (119). O, para decirlo con De Certeau, la escuela se presenta a sí misma como un lugar sin historia, transmisor de verdades irrefutables que van más allá de los avatares circunstanciales de lo ideológico: es el punto actual y pasajereo de un viaje, pero ha obrado sobre su propia imagen "the erasure of the itineraries" (de Certeau 121). Allí donde Vallejo, marxista heterodoxo y obviamente prealthusseriano, alcanza a ver en la escuela una traza de la superestructura, una arista del campo social y un jirón microcósmico de la lucha de clases, Acevedo, en cambio, distingue a la vez su carácter como ordenador ideológico y la historicidad conflictiva de su organismo. El mecanismo lo describe Acevedo sistemáticamente: en principio, señala el origen de la estructura de poder en la imagen del padre de Humberto Grieve, Dorian Grieve, alcalde y gerente de una ferrocarrilera extranjera. Si, en Vallejo, Humberto Grieve es un niño abusador que utiliza el poder de su padre para reproducirlo en el colegio, en Acevedo la relación es más de identidad que de vicariato: el niño es una instancia del padre al interior de la escuela (Fig. 22):

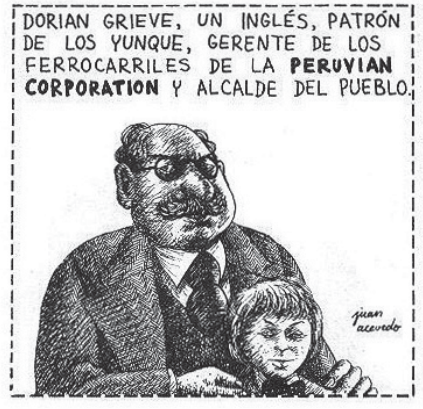

Fig 22. Pag. 3. Viñeta 11.

Pero no es la única, ni la más compleja. En cierto pasaje de su relato, Vallejo explica largamente la posición del padre en la estructura social, económica y política del pueblo. Lo hace desde la focalización del niño Paco Yunque: “Todos le tenían miedo”, dice. "Porque el señor Grieve hablaba muy serio y estaba mandando siempre. Y venían a su casa señores y señoras que le tenían mucho miedo y obedecían siempre al patrón y a la patrona. En buena cuenta, el señor Grieve podía más que el profesor y más que todos” (400-1). Más adelante, recurriendo al mismo punto de vista, el de Paco, la narración, aludiendo al maestro, extiende el retrato de las difrencias entre unos y otros: "No era el profesor igual a su papá ni al señor Grieve. Más bien se parecía a otros señores que venían a la casa y hablaban con el patrón” (401). En Vallejo, está claro, la intención es mostrar una escalera de tres peldaños, en el más alto el blanco de origen inglés, Grieve, autoridad política y poder económico; en el segundo, el profesor, mestizo urbano,

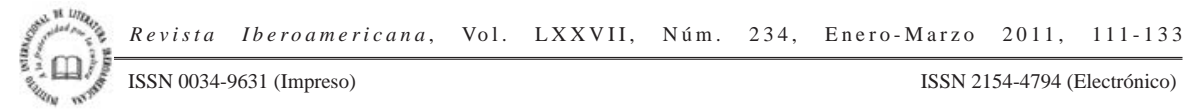


ilustrado pero relegado a la posición de un burócrata al servicio del orden estatal; en el tercero, el padre de Paco, la figura ausente, sin rostro, tan victimizado como el hijo, un indio andino sometido por el resto de la estructura. Singularmente, sin embargo, en su relectura, Acevedo decide tomar la representación de manera distinta: si en el cuento original el maestro "se parecía a otros señores que venían a la casa y hablaban con el patrón”, en la historieta de Acevedo, sin variar las palabras, el profesor se convierte, de hecho, en uno de esos visitantes, siervos sometidos directamente a la autoridad del señor Grieve, según cuyos caprichos, ánimos y expectativas ha de actuar su vasallo (Fig. 23).

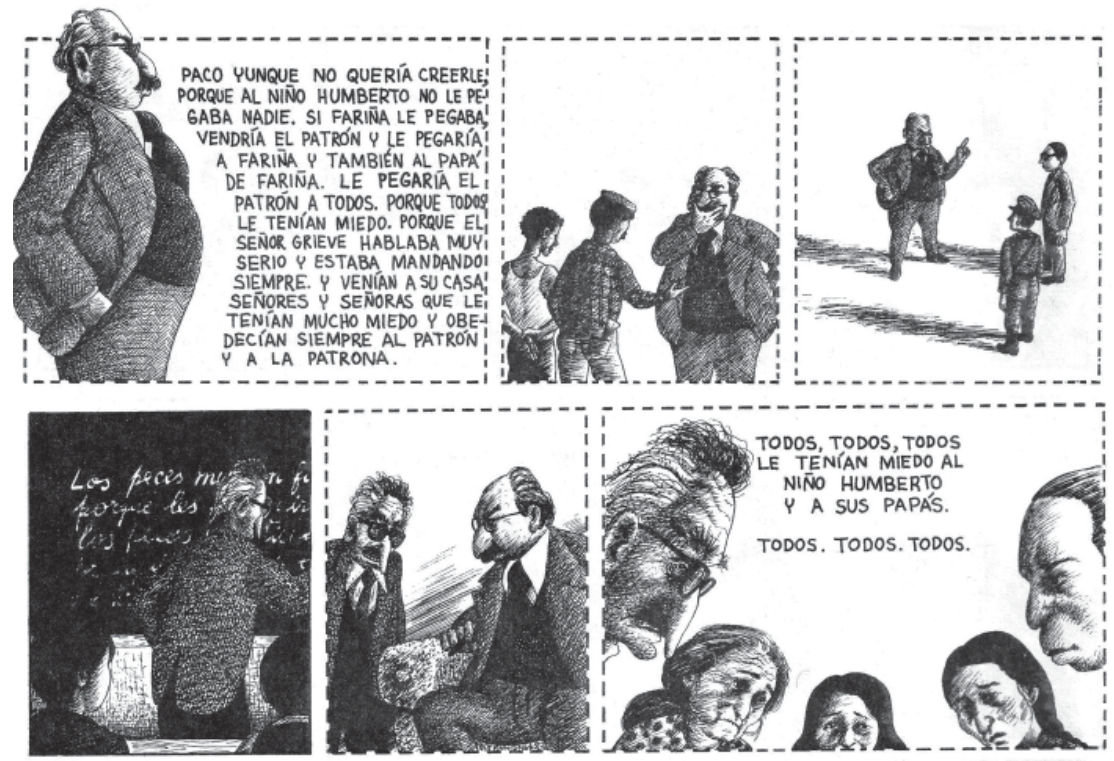

Figura 23. Pag. 13. Viñetas 4, 5, 6, 7, 8, y 9.

En esa secuencia de seis cuadros, la yuxtaposición de las imágenes es abarcadora y central: el señor Grieve ejerce su dirección sobre obreros, burócratas, policías, empleados y, crucialmente, sobre el maestro de la escuela. El cuarto y el quinto cuadro dejan claro que el maestro es, en su función pedagógica, un amanuense y un transmisor de los dictados del señor Grieve. El espacio de la escuela empieza a transparentar su contenido estructural: las actitudes del maestro ante los estudiantes varían no sólo según sus propios prejuicios ante la posición social de las familias de los niños, sino de acuerdo con las premisas ideológicas del padre de Grieve, es decir, según las necesidades del grupo dominante de amansar, domesticar, educar y reprimir a través de la institución escolar. La mano abierta del maestro ante Grieve, su dedo acusador ante Paco Fariña, su puño amenazante ante Paco Yunque (Fig. 24) cobran todas un sentido orgánico, funcional.

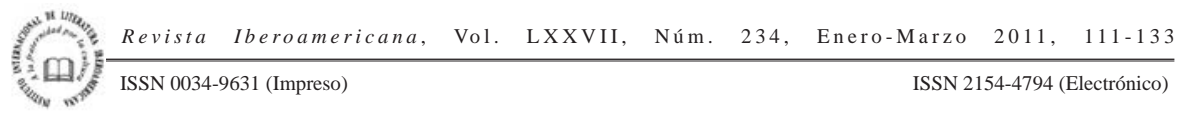




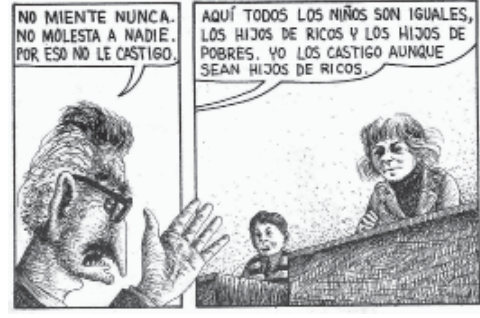

Fig. 24. Pag. 12. Viñetas 2 y 3.

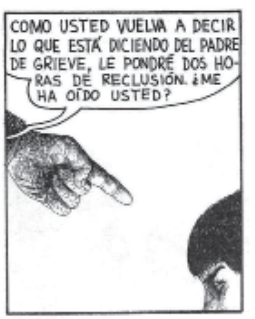

Pag. 12. Viñetas 4 y 5.

Los puños de Humberto Grieve se vuelven, entoces, sucedáneos y no enemigos de los puños del maestro mismo (Fig 25). Y con ello, finalmente, se transparenta el hecho de que los enfrentamientos eventuales entre el profesor y el niño Grieve (Fig. 26) no tienen la misma naturaleza que los choques entre el maestro y los demás niños: son, en el mejor de los casos, los coletazos angustiosos lanzados desde el lugar menos privilegiado de la escuela como Aparato Ideológico del Estado: el profesor es su pieza ineludible, pero también es la pieza menos poderosa, la menos decisiva, pues no puede hacer otra cosa que girar en el sentido en que gire el resto de la maquinaria.

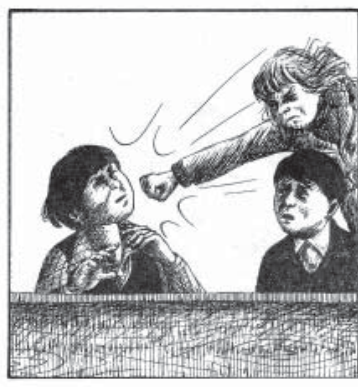

Fig. 25. Pag. 10. Viñeta 4.

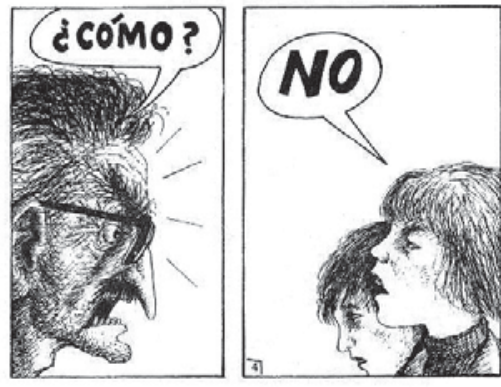

Fig. 26. Pag. 4. Viñetas 13 y 14.

“Ideology has no history”, escribe Althusser (121), no dictando una verdad en la que creyera, sino intentando expresar la situación tal como la misma ideología quiere presentarla: mostrándose como discurso inmanente, intangible, verdades que existen en independencia del devenir histórico. Lo mismo puede decirse de la apetencia de la estructura social: los discursos que la justifican escamotean el filo de su historicidad, se pretenden más allá de lo circunstancial. En su cuento, Vallejo dilucida la injusticia de la estructura, pero la reduce a su versión más simple: el dibujo que le entregó a la editorial (Fig. 1) es el esquema mínimo de la opresión social. El dibujante que ilustró el relato lo hizo incluso más reduccionista (Fig. 26):

Revista Iberoamericana, Vol. LXXVII, Núm. 234, Enero-Marzo 2011, $111-133$
ISSN 0034-9631 (Impreso) 


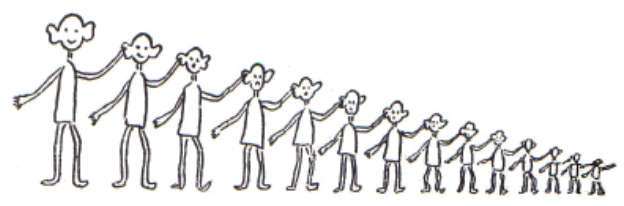

Fig. 26. Dibujo que ilustra la primera edición de "Paco Yunque” (1931).

Acevedo no se conforma con esa reducción, y quiere subrayar la historicidad, el devenir y la mecánica del proceso por el cual la ideología consume y fagocita incluso los signos que la sociedad en resistencia lanza contra ella. Por un lado, resignifica la famosa ilustración de la primera edición, deslizando que su autoría es del mismo Humberto Grieve, a quien, en cierto momento, retrata dibujando trazos infantiles muy similares a los de aquella vieja ilustración (Fig. 27): es decir, Acevedo asume el dibujo no con el papel explicativo pero simplificador que le otorgaba Vallejo, sino convirtiéndolo en el programa de la opresión, el diseño de esa cadena que es a la vez pirámide trunca y que expresa, ahora, en esta nueva versión, más que una denuncia, el deseo de la dominación. Por otro lado, Acevedo, dando un paso metatextual muy consciente, decide inscribir, en la trama de la historieta, la precedencia del original: en la pizarra del salón, junto al mapa del Perú, en esa misma galería de símbolos patrios donde antes ha colocado las imágenes de Unanue, Grau y Bolognesi, en una letra tenue, dejada como una reliquia de historias dichas con anteriorirdad, el lector encuentra escrito el nombre "César Vallejo" (Figura 28).

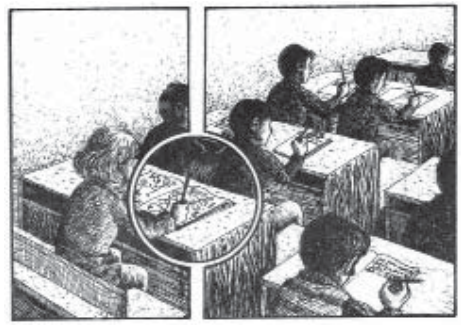

Fig. 27. Pag. 14. Viñetas 9, 10 y 11.

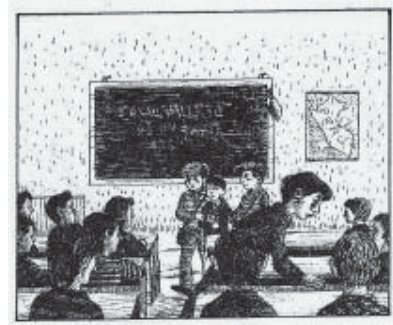

Figura 28. Pag. 2. Viñeta 4.

En ese punto, la historieta de Acevedo abre dos planos temporales paralelos pero concomitantes: uno en el que ella representa, pone en escena e interpreta el texto original de Vallejo, es decir, donde el relato de 1931 regresa y es actualizado; y otra en la que la versión de Acevedo se distingue del original, precisamente, porque lo coloca como antecedente, lo historiza, lo compromete en su propia genealogía. Aún más: si el nombre

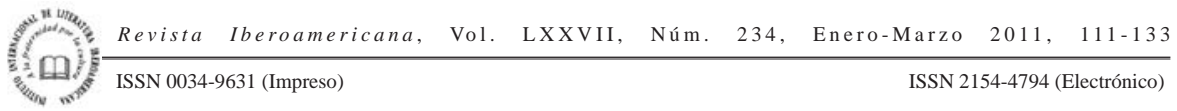


de Vallejo aparece sobre los mismos muros que muestran los íconos tradicionales del estado-nación peruano -Unanue, Grau, Bolognesi, el mapa republicano-, entonces, es entendible que, en el relato de Acevedo, el Paco Yunque original ya ha sido asimilado, digerido y convertido en un saber acaso inocuo, parte del derrotero con que la ideología, forjada en la escuela, en tanto Aparato Ideológico del Estado, borra las estaciones de su pasado, integrando en su seno, ya exceptuados de su valor subversivo, incluso los discursos que le han sido ajenos, contrarios o disidentes. En ese giro metatextual, el "Paco Yunque" de Acevedo pretende señalar la forma en que, habiéndose mantenido en el tiempo la estructura de la explotación y la inequidad social, es decir, las condiciones reales de la existencia de las clases sometidas, el Estado y sus Aparatos Ideológicos han sido capaces de adaptar su discurso para representar una nueva relación imaginaria entre el individuo y esas condiciones reales de existencia: la rebeldía del texto de Vallejo -rebeldía sui generis, que toma como signo crucial a ese ser pasivo y silencioso que es el primer Paco Yunque- se vuelve contra su intención primera: el objeto al que critica -los discursos hegemónicos- lo asimila y lo incluye, lo recibe y lo castra. En ese punto, la tensión del dentro y el fuera se extiende hasta su máxima longitud: "ideology has no outside (for itself) but at the same time [...] it is nothing but outside (for science and reality)" (Althusser 131): es imposible hablar, estar o ser fuera de la ideología, pues el mecanismo de la dominación se basa en la total inclusión y esterilización de los discursos disidentes, a los que integra, normaliza e inutiliza: la canonización de "Paco Yunque" lo vuelve parte del discurso contra el cual se alzaba originalmente. En su tramo final, la versión de Acevedo pone el dedo sobre esa llaga: la dominación "por ideología” y la pura represión de la violencia se reúnen para silenciar toda voz contradictoria (Fig. 29).
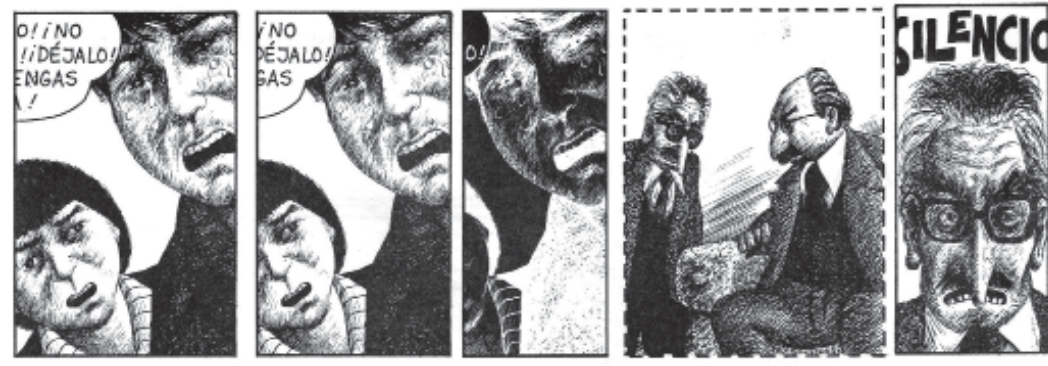

Fig. 29. Pag. 20. Viñetas 1, 2, 3, 4 y 5.

En una cosa coinciden el texto de Vallejo y la versión gráfica de Acevedo: en ambas un asomo de rebeldía amenaza con insuflar de vitalidad contestataria al lugar que es la escuela para hacerlo espacio vivo, escenario de un movimiento social de respuesta. En las dos, ese atisbo contradictorio es dominado y reprimido (Humberto Grieve, habiendo robado las tareas de Paco, recibe el premio como mejor alumno de la clase; Paco Yunque

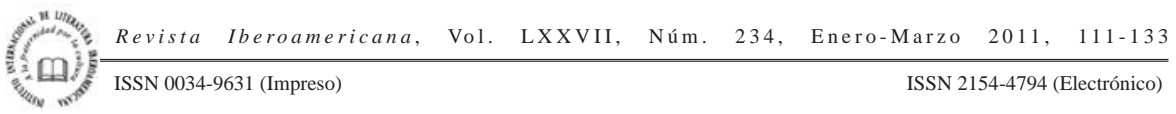


queda reducido al silencio; Paco Fariña es dejado inerme). La noción althusseriana del Aparato Ideológico del Estado no como mero instrumento sino como escenario de la lucha por la hegemonía, que me he permitido trasladar, simbólicamente, a los términos espaciales de De Certeau -donde el aliento de la contradicción se convierte en el impulso de transformar un lugar inmóvil en un espacio dinámico y contraventor7-, permite distinguir esa similitud, pero también poner en relieve la divergencia de ambas versiones: en Vallejo, marxista, sí, pero pesimista antes que todo, la escuela funciona como la proverbial rueda del universo, hecha de giros infinitos, contra la cual cada rebeldía se torna inútil y cada oposición acaba en renuncia. En Acevedo, el mecanismo es imbricado en un tejido histórico, puesto en perspectiva, y queda potenciado el valor de la rebelión por el paralelo con la iconografía tupacamarista: Paco Yunque revive para volver a caer, pero sabemos que la suya no es una derrota irremisible, sino una lucha que puede continuar.

La adaptación gráfica que Acevedo ejecuta a partir del cuento de Vallejo consigue dotar a la narración de una nueva vitalidad, recolocarla en la historia literaria peruana y en un nuevo periodo, a partir de una estética sutilmente diferente: allí donde Vallejo buscaba el lenguaje naif de la infancia, Acevedo busca la irónica duplicidad de una inocencia ambigua, alimentada por la referencia al relato de Vallejo y a la posición de su autor en el canon peruano. "Paco Yunque" -es bueno recordar esto- fue una de esas raras excepciones en las que Vallejo decidió dejar de lado enteramente la experimentación vanguardista, que, en su obra, por lo común, mucho tenía que ver con la estética figurativa de las vanguardias pictóricas, el surrealismo y el cubismo sobre todo. Si Vallejo lo hizo, no es arbitrario especular que su intención autorial fue la de elaborar un relato de llegada amplia, de fácil recepción, accesible para el lector más inmediato y no iniciado tanto como para el más entrenado. Acevedo respeta esa premisa, construyendo él mismo una narración de lectura directa, que no descarta siquiera al receptor infantil. Pero, echando mano de esa sencillez formal, tomada de Vallejo, Acevedo también se enfrenta al problema de no desconocer la preexistencia del texto canónico, y de incorporarlo a su propia adaptación, ensanchando con ello la aparente simplicidad para dotarla de esa profundidad interpretativa a la que he aludido antes. El trazo simple, que evoca a Hergé y anuncia al Chester Brown de Louis Riel, es la línea que Acevedo elige para otorgar un cierto carácter histórico a la historieta, carácter que, por supuesto, no tiene el original de Vallejo: en ese simple gesto estilístico, Acevedo reconoce la preexistencia de la fuente, y su presencia indeleble en el canon peruano.

\footnotetext{
7 "The awakening of inert objects (a table, a forest, a person that plays a certain role in the environment) which, emerging from their stability, transform the place where they lay motionless into the foreignness of their own space [...] The putting to death (or putting into a landscape) of heroes who transgress frontiers and who, guilty of an offense against the law of the place, best provide its restoration with their tombs” (de Certeau 118).
}

Revista Iberoamericana, Vol. LXXVII, Núm. 234, Enero-Marzo 2011, $111-133$
ISSN 0034-9631 (Impreso) 


\section{BIBLIOGRAFÍA}

Acevedo, Juan. Túpac Amaru. Vols. I y II. Lima: Tarea, 1985. y Carlos Jiménez. Paco Yunque. Lima: Editorial San Marcos, 2008.

Althusser, Louis. "Ideology and Ideological State Apparatuses (Notes towards an Investigation)”. Mapping Ideology. Slavoj Žižek, ed. New York: Verso, 1994. 100-40.

Arendt, Hannah. On Violence. New York: Harcourt Brace \& Company, 1969.

Bachelard, Gaston. The Poetics of Space. Maria Jolas, trad. Boston: Beacon Press, 1969.

Bourdieu, Pierre. Language and Symbolic Power. Gino Raymond y Matthew Adamson, trads. Cambridge: Harvard UP, 2001.

Certeau, Michel de. The Practice of Everyday Life. Steven Rendall, trad. Berkeley: U of California P, 1984.

Vallejo, César. “Paco Yunque”. César Vallejo, Narrativa completa. Lima: Pontificia Universidad Católica del Perú, 1999. 387-407.

Revista Iberoamericana, Vol. LXXVII, Núm. 234, Enero-Marzo 2011, $111-133$
ISSN 0034-9631 (Impreso) 
